\title{
糖尿病の関与した歯周病が急性悪化した一症例
}

\author{
堀口優美石田ひとみ 涉 谷 俊 昭 \\ 白木雅文岩山幸 雄 \\ 朝日大学歯学部歯周病学講座 \\ （主任 : 岩山幸雄教授） \\ (昭和 62 年 6 月 19 日受付)
}

\section{A Case of Rapidly Destructive Periodontitis Associated with Diabetes Mellitus}

\author{
Yumi HORIGUCHI, Hitomi ISHIDA, Toshiaki SHIBUTANI, \\ Masafumi SHIRAKI and Yukio IWAYAMA \\ Department of Periodontology, Asahi University, School of Dentistry
}

(Chief : Prof. Yukio IWAYAMA)

The patient was a 38 year-old male with moderate chronic marginal periodontitis. Probing depth and bleeding index were reduced by oral hygiene instruction, scaling and root planing for three months. After the treatment, acute periodontal abscesses were formed frequently and bone loss appeared radiograph- ically. Oral hygiene instruction and root planing were performed again, but the treatment had no apparent effect. Suspecting the influence of systemic factors, we tested the blood. The data showed a high level of blood sugar (advanced diabetes mellitus) and altered regulation of the immune response.

Key Words : Marginal periodontitis, Diabetes mellitus, Peripheral lymphocytes

要旨 : 38 歳の初期から中等度の辺縁性歯周炎の患者に初期治療を行い, 良好に治㽷したため, メインテナンスに入 ったが，6カ月経過した頃より歯周膿瘍の多発と急速な骨吸収像が現れた。再び治療を行ったが，効果が認められな いため, 全身的要因を疑い血液検査を行った。その結果, 進行した糖尿病の存在と免疫機構の不全が起こっていると 考えられる所見が認められた症例について報告した。

索引用語 : 辺縁性歯周炎, 糖尿病, 末梢血リンパ球

\section{緒言}

従来から, 糖尿病患者においては, 慢性辺縁性歯周炎 の罹患率が高いと報告されている ${ }^{1,2)}$ 。Williams ${ }^{3}$ ～は糖 尿病時にみられる歯周炎を, 糖尿病の特徵的な病変であ るとみなして, 糖尿病性歯周破壊症 (diabetic periodontoclasia）と名付けた。

糖尿病が関与した辺縁性歯周炎の臨床的特徵として, 強い歯肉の炎症, 深い歯周ポケット, 高度の歯の動摇,
多発性膿陽の形成, 歯槽骨の強い吸収, 速やかな進行, 難治などが挙げられている4)。また一般にコントロール されていない糖尿病と歯周炎が共存する場合において， はじめて典型的で重篤な症状が現れると考えられてい $る^{5)}$ 。

今回著者らは, 初期から中等度の辺縁性歯周炎の患者 で, 初期治療においては順調な治癒経過をたどりメイン テナンスに進んだが，約 6 カ月経過した頃から，歯周膿 瘍の多発と急速な骨吸收像を認めたため, 再び歯周治療 を行ったが, その効果がほとんど認められないことから，

本論文の要旨は, 第 30 回春季日本歯周病学会総会（1987 年 4 月 18 日）において発表した。 
表 1 口腔内診査結果

\begin{tabular}{lcc}
\hline & 初診時 & 初期治療終了時 \\
\hline 平均プロービングデプス & $2.7 \mathrm{~mm}$ & $2.3 \mathrm{~mm}$ \\
出血指数 & $62.5 \%$ & $14.3 \%$ \\
\hline
\end{tabular}

表 2 口腔内診査結果

\begin{tabular}{lc}
\hline \multicolumn{2}{c}{ 治療終了後 6 力月 } \\
\hline 平均プロービングデプス \\
出血指数
\end{tabular}

全身的要因の疑いを持ち，血液検查を行った結果，進行 した糖尿病の存在を認めた症例を経験したので 報告す る。

\section{症例}

患 者: 38 歳, 男性

初診: 昭和 59 年 2 月 29 日

主 訴: 7 部煩側の歯周膿場

既往歴：特記事項なし

\section{家族歷 : 父親が糖尿病}

現病歴: 昭和 59 年 2 月 28 日早朝より下顎右側臼歯部 に拍動痛を認め, 夜には疼痛が増大し, 咬合痛も著しい ため, 翌 29 日に来院した。

現 症

全身所見 : 体格，栄養状態ともに良好

口腔内所見 : 全体的に辺縁歯肉の発赤, 腫脹と退縮が 認められ，7部頓側は膿場を形成し，波動が触診できた。 また同部の probing depth は $7 \mathrm{~mm}$ であった。

全澦の平均 probing depth は $2.7 \mathrm{~mm}$ であり, 歯の 動摇はほとんど認められなかった（図 1, 表 1)。

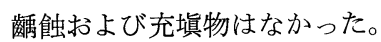

$\mathrm{X}$ 線所見：骨頂部のわずかな水平性骨吸収が，犬歯部 から兒歯部にかけて認められた（図 2)。

処置および経過 : 7 部の膿瘍を切開, 排膿後, 約 3 力 月間, プラークコントロールとスケーリング・ルートプ レーニングを中心とした初期治療を行った。その結果, 平均 probing depth は $2.3 \mathrm{~mm}$, 出血指数は $14.3 \%$, また7部䫅側の probing depth は $3 \mathrm{~mm}$ と改善され た（図 3, 表 1 )。プラークコントロールの状態む良好 (5.4\%) であったため, この時点でメインテナンスに入 った。

初期治療終了後, 6 カ月後のリコール時には, 平均

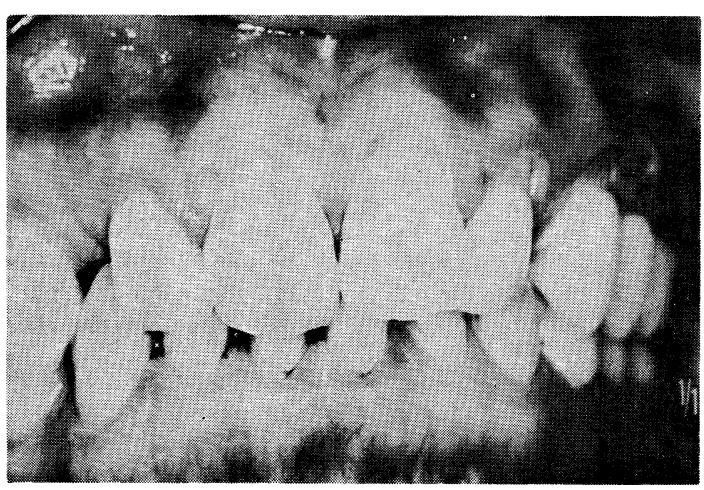

図 1 初診時口腔内写真

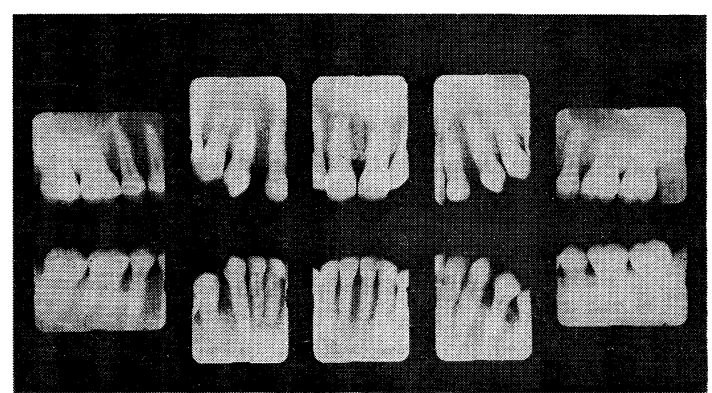

図 2 初診時X線写真

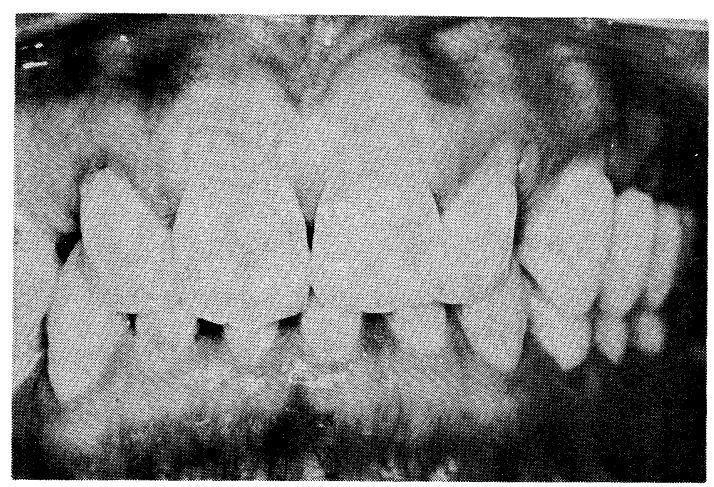

図 3 治療終了時口腔内写真

probing depth $2.2 \mathrm{~mm}$, 出血指数も $17.9 \%$ と良好な状 態を維持していて，X線所見も初診時と比べてほとんど 変化はなかった（図 4, 表 2)。

しかしこのリコールから 1 週間後に，5部口蓋側に歯 周膿瘍を形成して来院した。そこでしばらく来院期間を 短かくして, professional tooth cleaning を行っていた が，その後も治療終了後 8 力月と 11 力月に 7 部煩側に 膿瘍を形成した。その時点で7部の歯周外科処置を計画 したが，患者が来院しなくなった。 


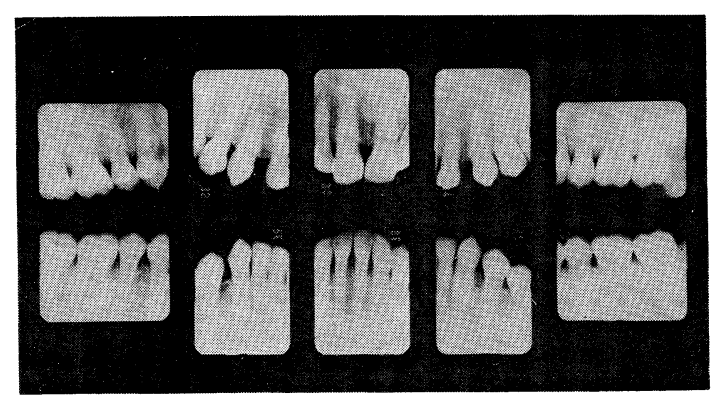

図 4 治療終了後 6 力月 X線写真

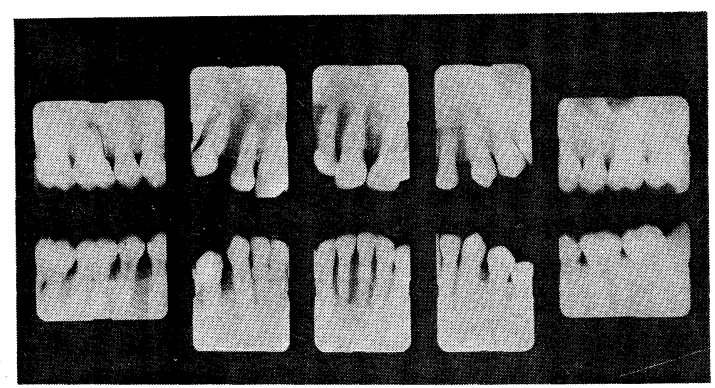

図 5 治療終了後 1 年 8 力月 X線写真

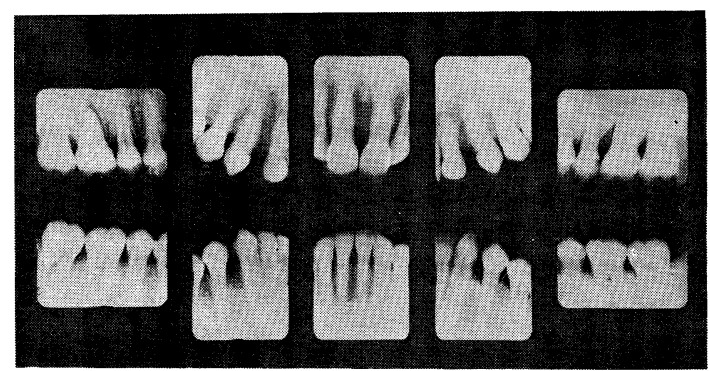

図 6 治療終了後 2 年 3 力月 X線写真

治療終了後 1 年 8 力月時に 6 の咬合痛を主訴として再 来院した。X線写真 (図 5 ) では，61近心根根尖部に暗 影像が認められた。また, 歯周膿瘍を繰り返した7 7 の分 岐部の骨の消失が著明であった。歯髄診断の結果，61は 失活歯であることが判明したので, 直ちに感染根管処置 を行うとともに，出血指数が $51.8 \%$ と上昇していたた め, 再度プラークコントロールを行った。ところが治療 中に迆部に膿瘍を形成した。X線像から咬合性外傷を疑 って精查したが特に問題なく, また局所的にも十分コン トロールできているにも関わらず，出血指数の上昇や頻 繁な膿瘍形成を認めるため, 全身的要因を疑って, 血液 学的検查を行った。その結果, 表 3 に示すように, 白血 球数拉よび $\gamma$ ーグロブリンが低数值であった。またグル コース・オキシダーゼ法による食後 2 時間の 血糖值は
表 3 血液検查結果 治療終了後 1 年 8 力月

\begin{tabular}{|c|c|c|c|}
\hline & & & 正常值 \\
\hline & 球数 & 5300 & $4500 \sim 8500$ \\
\hline & 球数 & 516 & $435 \sim 565$ \\
\hline & グロビン & $15.6 \mathrm{~g} / \mathrm{d} l$ & $12.4 \sim 17.2 \mathrm{~g} / \mathrm{d} l$ \\
\hline & トクリット & $54 \%$ & $39 \sim 52 \%$ \\
\hline & & $6.7 \mathrm{~g} / \mathrm{d} l$ & $6.5 \sim 8.0 \mathrm{~g} / \mathrm{d} l$ \\
\hline & & 1.83 & $1.1 \sim 1.8$ \\
\hline & アルブミン & $64.6 \%$ & $57.0 \sim 69.0 \%$ \\
\hline 蛋 & $\alpha_{1}$-グロブリン & $4.4 \%$ & $1.7 \sim 4.5$ \\
\hline 日 & $\alpha_{2}$-グロブリン & $10.9 \%$ & $6.0 \sim 11.0$ \\
\hline 分 & $\beta$-グロブリン & $8.9 \%$ & $6.5 \sim 12.0$ \\
\hline 四 & $\gamma$-グロブリン & $11.0 \%$ & $11.5 \sim 22.0 \%$ \\
\hline & 值 $472 \mathrm{mg} / \mathrm{d} l$ & (食後 2 時間) & \\
\hline
\end{tabular}

表 4 末梢血リンパ球 subset の分布率 治療終了後 1 年 8 力月

\begin{tabular}{lc}
\hline $\mathrm{OKT}^{-} 3^{+}$ & $80.30 \%$ \\
$\mathrm{OKT}^{-} 4^{+}$ & $50.00 \%$ \\
$\mathrm{OKT}^{+} 8^{+}$ & $17.80 \%$ \\
$\mathrm{OKT}^{+} / \mathrm{OKT}^{+}$ & 2.81 \\
LEU $-12^{+}$ & 5.20 \\
\hline
\end{tabular}

$472 \mathrm{mg} / \mathrm{d} l$ と高く, 重度の糖尿病の存在が判明した。こ の時の患者の問診では, 口渴, 体重の減少などを訴えた。 同時に行った竹内 $\check{5}^{6}$ の方法による末梢血リンパ球 少 ブセットの検索の結果 (表 4) は, OKT $3^{+}$が高く, LEU $12^{+}$が低く, また OKT $4^{+} / \mathrm{OKT} 8^{+}$比が 2.81 と高い值 を示した。

その後某医院にてオイグルコンの経口投与を受けると ともに，家庭での食事療法を行っていたが，空腹時血糖 值が常に $200 \mathrm{mg} / \mathrm{d} l$ をうわまわり，血糖值は全くコント ロールできていない状態であった。そのために professional tooth cleaning を行いながら, 時期を見て, $\frac{6 \mid 6}{7 !}$ については歯周外科を実施する予定であったが，その機 会がなかった。

図 6 は治療終了後 2 年 3 力月時のX線写真である。膿 瘍を頻発した $\frac{\mid 6}{7 \mid}$ の骨吸収が著名に認められ, 感染根管 処置を行った 6 の治療状態も良好とは言えなかった。図 7 はそれから 4 力月後のX線写真である。迆の骨吸収が さらに進行している像が認められた。

その後再び血液検査を実施した結果, 白血球数の増加 はなく, 行った末梢血リンパ球サブセットの検索の 結 果（表 6 ） も, 前回と同様に OKT $3^{+}$および OKT $4^{+} / \mathrm{OKT} 8^{+}$比が 
表 5 血液検查結果 治療終了後 2 年 7 力月

\begin{tabular}{|c|c|c|c|}
\hline & & \multicolumn{2}{|r|}{ 正常値 } \\
\hline \multicolumn{2}{|c|}{ 白血球数 } & 7100 & $4500 \sim 8500$ \\
\hline \multicolumn{2}{|c|}{ 赤血球数 } & 470 & $435 \sim 565$ \\
\hline \multicolumn{2}{|c|}{ へモグロビン } & $16.8 \mathrm{~g} / \mathrm{d} l$ & $12.4 \sim 17.2 \mathrm{~g} / \mathrm{d} l$ \\
\hline \multicolumn{2}{|c|}{ ヘマトクリット } & $47 \%$ & $39 \sim 52 \%$ \\
\hline \multicolumn{2}{|c|}{ 続蛋白 } & $6.9 \mathrm{~g} / \mathrm{d} l$ & $6.5 \sim 8.0 \mathrm{~g} / \mathrm{d} l$ \\
\hline \multicolumn{2}{|c|}{$\mathrm{A} / \mathrm{G}$ 比 } & 2.25 & $1.1 \sim 1.8$ \\
\hline \multirow{5}{*}{$\begin{array}{l}\text { 蛋 } \\
\text { 白 } \\
\text { 分 } \\
\text { 画 }\end{array}$} & アルブミン & $69.3 \%$ & $57.0 \sim 69.0 \%$ \\
\hline & 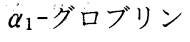 & $3.4 \%$ & $1.7 \sim 4.5 \%$ \\
\hline & $\alpha_{2}$-グロブリン & $9.2 \%$ & $6.0 \sim 11.0 \%$ \\
\hline & $\beta$-グロブリン & $8.8 \%$ & $6.5 \sim 12.0 \%$ \\
\hline & $\gamma$-グロブリン & $9.2 \%$ & $11.5 \sim 22.0 \%$ \\
\hline
\end{tabular}

表 6 末梢血リンパ球 subset の分布率 治療終了後 2 年 7 力月

\begin{tabular}{lc}
\hline $\mathrm{OKT}^{-} 3^{+}$ & $80.23 \%$ \\
$\mathrm{OKT}^{+} 4^{+}$ & $61.82 \%$ \\
$\mathrm{OKD}^{+} 8^{+}$ & $18.07 \%$ \\
$\mathrm{OKT}^{+} / \mathrm{OKT}^{+}$ & 3.42 \\
$\mathrm{LEU}^{+}-12^{+}$ & $7.61 \%$ \\
\hline
\end{tabular}

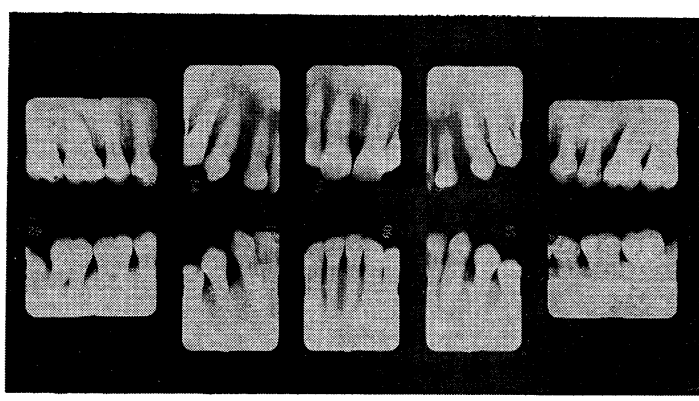

図 7 治療終了後 2 年 7 力月 X線写真

高く, LEU $12^{+}$が低い值を示した。空腹時血糖值は 230 $\mathrm{mg} / \mathrm{d} l$ であった。

\section{考察}

糖尿病はなんらかの遺伝的因子を有するものに, 肥満, ストレス，インスリンに拮抗するホルモンの増加などが 加わって発症する疾患である。このような糖尿病の遺伝 的因子や後天的因子はまだ十分には解明されておらず， 生化学的, 組織学的, あるいはホルモン性の異常も伴い, 一種の症候群と考えられている ${ }^{7,8) 。 ~}$

糖尿病患者において, 慢性辺縁性歯周炎の罹患率が高 いことは古くから報告されていて，山田 ${ }^{2)}$, 中山ら ${ }^{99}$ の調
查では, 糖尿病患者の歯周疾患罹患率は $75 \%$ にも達す ると報告されている。

本学付属病院の外来でも, 糖尿病を有する歯周疾患患 者は多い。しかしこれらの症例は, 患者本人が糖尿病で あることを自覚していて，なんらかの処置を受けている 場合がほとんどである。そのためにまったくコントロー ルされていない重症の糖尿病患者に遭遇することはまれ である。良好にコントロールされている糖尿病患者の場 合, 池田 ${ }^{10)}$ も述べているように特に健康人と比べて問題 はないと思われる。口腔内を良好な状態に保つことがで きるならば，歯周組織の破壊をストップさせることはさ ほど困難ではない。もちろん歯周外科を行うことも可能 であるし，感染防止に細心の注意をはらえば，術後の治 療も良好である。

本症例の場合, 糖尿病の発症の時期は不明であるが, 初診時には口渴などの自覚症状がまったくなかったこ と, また初期治療を行ったときの治療が順調であったこ とから，発病時期はメインテナンスに入った頃からでは ないかと推察される。糖尿病は家族性に発症することが 注目され, Naunyn は糖尿病遺伝説を発表し11)，今日では 糖尿病の成立に遺伝の関与があることはまったく疑う余 地がない。本症例においても父親が糖尿病であり, 冒頭 に述べたように遺伝的因子があるところに，なんらかの 後天的因子が加わって急激に発症し, 悪化をしたものと 考えられる。成人型の糖尿病では肥満が原因であること が非常に多く ${ }^{12)}$, 標準体重より $50 \%$ 以上肥満の人 では 標準体重の人より 7 倍む発症しやすいという報告8) あ る。また糖尿病の進行とともに体重の隇少をきたすと言 われている。本症例の患者は初診時の身長は約 $170 \mathrm{~cm}$, 体重は $59 \mathrm{~kg}$ であり，糖尿病発見時は $55 \mathrm{~kg}$ であった。 体格はむしろ瘦せ型であり, 糖尿病の突然の出現や，才 イグルコンの投与によっても血糖值が降下しないことな どから，むしろ若年型糖尿病に近いのではないかと推察 される。

糖尿病患者において, 慢性辺縁性歯周炎の罹患率が高 い理由として, 血管障害と, 感染に対する抵抗力の低下 が挙げられる ${ }^{8)}$ 。村瀬ら ${ }^{13)}$ は, 歯肉毛細血管を調べた結 果, 糖尿病患者では健常者に比べて, その数が減少し, 屈曲が強くなっていると報告している。糖尿病時に毛細 血管に生じる血管障害は, diabetic microangiopathy と 名付けられ7)，毛細血管の基底膜の肥厚を伴う透過性の 六進がおこると報告されている14,15)。これらの血管障害 により, 歯周組織の抵抗力が減弱し, また修復能力も劣 るものと考えられる。本症例においても，血管障害が， 
出血指数を増加させる原因となったと思われる。

Miller ら ${ }^{16)}$ は歯周ポケット内の好中球が, 細菌やそ の産生物が歯周組織へ進入するのを防ぐ働きをすると報 告している。しかし, 糖尿病患者においては好中球の遊 走能や食作用の低下が起こっていることが明らかにさ れ ${ }^{17,18)}$, さらに糖尿病の家系と好中球遊走能不全との間 に関連があるという McMullen ら ${ }^{19)}$ の報告もある。以 上のことは，糖㽷病患者における歯周炎の罹患率の高さ と，進行の速さを説明するものと思われる。

今回の報告では，好中球の機能については検索してい ないが，頻発する膿瘍などから，感染に対する抵抗力の 低下が伺える。

末梢血リンパ球の解析は, 生体の免疫機構を知る上で 有益であると考えられる。末梢血リンパ球サブセットの 解析を行った竹内ら ${ }^{6)}$ の報告では，歯周炎患者は健常人 に比べて, OKT $4^{+}$と OKT $4^{+} / \mathrm{OKT} 8^{+}$比が有意に高く, また OKT $8^{+}$と LEU $12^{+}$が低い值であった。本症例の 場合は, 二度の検索ともに OKT $4^{+}$と OKT $4^{+} / \mathrm{OKT} 8^{+}$ 比は歯周炎患者の平均よりさらに高く, 反対に OKT $8^{+}$ と LEU $12^{+}$はさらに低い值を示した。特にここで注目 したいのは OKT $4^{+} / \mathrm{OKT} 8^{+}$比, すなわち helper T cell と suppressor $\mathrm{T}$ cell の比である。この比は免疫調節機 構の恒常性の変動を示す一つのパラメーターとなるとい われていて ${ }^{20)}$, 馬止ら ${ }^{21)}$ の報告では, Sjögren 症候群, 関節リウマチ等の自己免疫疾患や， $\mathrm{A}$ 型肝炎，加齢など によって上昇し, 血友病, B 型肝炎, AIDS などでは低下 するとしている。糖尿病とこの比率の関係は不明である が, 細菌感染症によりこの比率の変化があることから ${ }^{6)}$, 糖尿病により悪化した歯周疾患の存在が, OKT $4^{+} / \mathrm{OKT}$ $8^{+}$比を上昇させる結果となったとも考えられる。またこ の比率が上昇すると, B-cell の分布率も増加するという 報告があるが6)，今回の二度の検索では B-cell の分布率 は非常に低かった。これは抗原に対して，当然抗体を産 生して免疫応答を開始すべきである B-cell が働いてい ないものと推察される。

$\gamma$ ーグロブリンは，体液性免疫で中心的役割を果してい る重要なタンパクであるが, 二度の血液検査で, 正常值 よりも低い值を示した。 免疫不全症候群, リンパ腫, 強直性筋ジストロフィなど

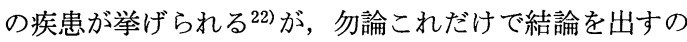
は妥当ではない。

以上の検索から, 本症例においてなんらかの免疫機構 の不全が起こっているのではないかということが示唆さ れる。それが糖尿病とどのように関係しているかは, 今
後さらに検討を加える必要がある。しかし, 糖尿病発病 以前の歯周組織の状態や治療経過が, Page and Schroeder ${ }^{23)}$ によって提唱されている rapidly progressive periodontitis と異なっていることは明白である。

今後の治療方針としては, 内科医と密接に連絡を取り, 糖尿病が良好にコントロールできた時点で, 早急に歯周 外科処置を行うとともに，再び血液検査および末梢血り ンパ球の解析を行いたいと考えている。

\section{結 論}

38 歳の辺縁性歯周炎の患者に初期治療を行い, 良好に 治癒したため, メインテナンスに入ったが，歯周膿瘍の 多発と急速な骨吸収像があらわれ，処置に反応しなくな ったため, 全身疾患を疑い血液検査を行った。その結果, 進行した糖尿病であることが判明した症例について報告 した。

\section{文献}

1）柴崎貞二, 西 裕之: 糖尿病患者における歯科疾 患の眻患状況についての研究. 糖 尿 病, $29: 39$ 47, 1986.

2) 山田弘三, 坂本信夫, 小出忠孝, 吉田雄彦 : 糖尿 病と歯槽膿漏. 糖尿病, $13: 303-310,1970$.

3) 秋吉正豊 : 歯周組織の構造と病理, 医歯薬出版, 東京, 1961，197-199.

4) Hirschfeld, I. : Periodontal Symptoms Associated with Diabetes. J. Periodont., 5 : 37-46, 1934.

5) 今川与曹, 石川 純 : 臨床歯周病学, 医歯薬出版, 東京, 1968,77 .

6) 竹内 宏, 田島一範, 涉谷俊昭, 勝谷芳文, 岩山 幸雄, 佐藤 勝, 上田雅俊 : 辺縁性歯周炎と免疫 機構 第 1 報 歯周炎患者の免疫機構, 成人性歯 周炎患者と健常人の末梢血リンパ球の解析. 日歯 周誌, 28 : 1054-1062, 1986.

7）暮谷英嗣, 井村裕夫, 小野尊睦 : 代謝系疾患と歯 科診療, 糖尿病. 日本歯科医師会, 歯科診療のた めの隣接医学, 医歯薬出版, 東京, 1979, 120-130.

8) Schluger, R.C. : 青野正男 (監訳)：シュルーガー 最新歯周治療学. 医歯薬出版, 東京, 1981. 253-263.

9）中山光重 : 歯槽膿漏と糖尿病の関係, 糖尿病, 8 : 133-134, 1965.

10）池田義雄 : 歯科治療にさしつかえない患者の状 
態. 池田義雄，内田安信. 糖尿病と歯科治療，デ ンタルダイヤモンド社, 東京, $1978,63-70$.

11）鈴木弘造 : 代謝系. 河村洋二郎, 歯科医のための 隣接医学. 医歯薬出版, 東京, 1974, 185-194.

12）池田義雄: 糖尿病の合併症. 阿部正和. 池田義雄, 内田安信, 糖尿病と歯科治療, デンタルダイヤモ ンド社, 東京, 1978, 71-114.

13）村瀬正雄, 高井 宏, 重藤 信, 足立 墚: 歯槽 膿漏症と糖尿病との関係, 東女医大誌， $33: 653-$ 657, 1963.

14) Frantzis, T.G., Reeve, C.M. and Brown, A.L. Jr. : The ultrastructure of capillary basement membranes in the attached gingiva of diabetic and non-diabetic patients with periodontal disease. J. Periodontol., 42 : 406-411, 1971.

15) Listgarten, M.A., Ricker, F.H., Jr., Shapiro, J. and Cohen, D.W : Vascular basement lamina thickness in the normal and inflamed gingiva of diabetics and non-diabetics. J. Periodontol, 45 : 676-684, 1974.

16) Miller, D., Lamster, I.B. and Chasens, A.I. : Role of the polymorphonuclear leukocyte in periodontal health and disease. J. Clin. Periodontol., $11: 1-15,1984$.

17) Molenaar, D.M., Palumbo, P., Wilson, W.R. and Ritts, R. : Leukocyte chemotaxis in dia- betic patients and their nondiabetic first degree relatives. Diabetes, $25: 880-883,1976$.

18) Manouchehr-Pour, M., Spagnuolo, P.J., Rodman, H.M. and Bissada, N.F. : Impaired neutrophil chemotaxis in diabetic patients with severe periodontitis. J. Dent. Res., 60 : 729-730, 1981.

19) McMullen, J.A., Van Dyke, T.E., Horoszewicz, H. and Genco, R.J. : Neutrophil chemotaxis in individuals with advanced periodontal disease and a genetic predisposition to diabetes mellitus. J. Periodontol., $52: 167-173,1981$.

20）松元康治, 大久保慶二, 横山三男 : フローサイト メトリーを用いたヒト末梢血リンパ球膜抗原の分 析一正常人の抗原分布について一. 臨床免疫, 16 : 862-872, 1984.

21）馬止 裕, 内山 卓：モノクローナル抗体を用、 たヒトリンパ球表面抗原の解析一正常および病的 状態における意義一. 臨床免疫, $16: 846-857$, 1984.

22）臨床検查医学事典編集委員会：臨床検 查 医 学 事 典, 初版. 朝倉書店. 東京. 1982, 193-194.

23) Page, R.C., Altman, L.C., Ebersole J.L., Vandesteen, G.E., Dahlberg, W.H., Williams, B.L. and Osterberg, S.K. : Rapidly progressive periodontitis : A distinct clinical condition. J. Periodontol., 54 : 197-209, 1983. 